\title{
Commentary: Promise of personalized tissue-engineered vascular grafts for congenital heart surgery
}

\author{
Ming-Sing Si, MD
}

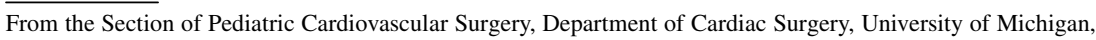
Ann Arbor, Mich.

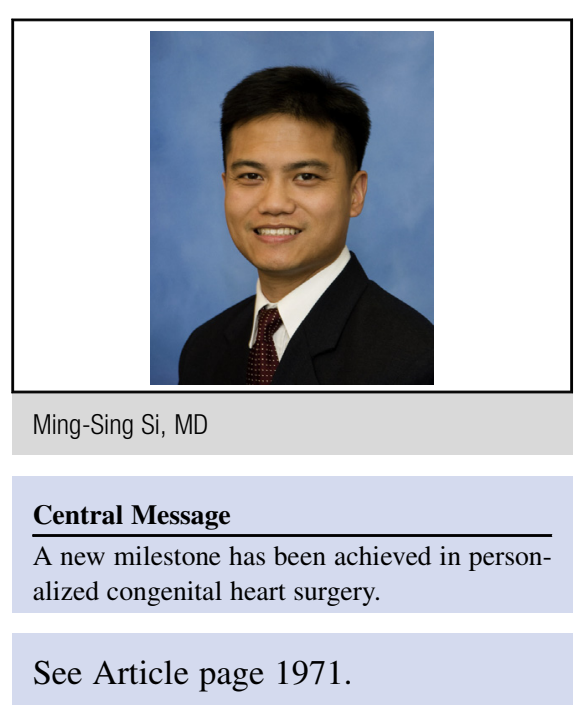

Vascular grafts and, more commonly, patches are commonly used in the repair of congenital heart defects. Non-autologous, circumferential vascular grafts have key shortcomings, such as the lack of growth potential and need for anticoagulation, that prohibit their universal adoption. ${ }^{1}$ Another shortcoming of grafts and patches is that tailoring of their shape and size before implantation is according to the surgeon's eye or crude measurements in 1 or 2 dimensions. Although this tailoring may be satisfactory for simple geometries, achieving the most efficient hemodynamic result for complex pathways and baffles in growing children is sometimes difficult, and the development of late obstruction may necessitate reoperation. ${ }^{2,3}$

In this issue of the Journal, the team of Yeing and colleagues ${ }^{4}$ presents their initial results of an innovative approach to the aforementioned shortcomings of the traditional vascular implant. These investigators used a multistep process that incorporates virtual surgical planning based on clinical imaging results, flow dynamic profile optimization, and the creation of a bespoke tissue-engineered vascular graft by electrospinning biodegradable nanofiber material on a 3-dimensional printed mandrel that was derived from the first 2 steps. For this pilot study, these investigators created bifurcated grafts that were then implanted into growing pigs $(n=2)$ as a replacement of the native distal main pulmonary artery as well as the proximal branch pulmonary arteries. During the 1-month study period, the animals increased in size by $33 \%$. Pressures measured in the branch pulmonary arteries were normal, and there was equivalent flow to both lungs. Histologically, the vascular grafts demonstrated endothelialization and the development of a vascular smooth muscle cell layer. However, there was minimal collagen-rich adventitia, and the results of the biomechanical testing of the explanted graft material were consistent with this.

The grafts that were implanted were larger than the native vessel but then contracted to the native size. Future long-
Ann Arbor, Mich.
Disclosures: Author has nothing to disclose with regard to commercial support.
Received for publication Oct 8, 2019; revisions received Oct 8, 2019; accepted for publication Oct 8, 2019
available ahead of print Nov 11, 2019.
Address for reprints: Ming-Sing Si, MD, 11-735 C.S. Mott Children's Hospital SPC 4204, 1540 E Hospital D
Ann Arbor, MI 48109-4204 (E-mail: mingsing@ umich.edu).
J Thorac Cardiovasc Surg 2020;159:1984-5
0022-5223/\$36.00
Copyright @ 2019 Published by Elsevier Inc. on behalf of The American Association for Thoracic Surgery
https://doi.org/10.1016/j.jtcvs.2019.10.014

Ann Arbor, Mich.
Disclosures: Author has nothing to disclose with regard to commercial support.
Received for publication Oct 8,2019 ; revisions received Oct 8, 2019; accepted for publication Oct 8, 2019;
available ahead of print Nov 11, 2019.
Address for reprints: Ming-Sing Si, MD, 11-735 C.S. Mott Children's Hospital SPC 4204, 1540 E Hospital Dr,
Ann Arbor, MI 48109-4204 (E-mail: mingsing@ @mich.edu).
J Thorac Cardiovasc Surg 2020;159:1984-5
0022-5223/\$36.00
Copyright $\subset 2019$ Published by Elsevier Inc. on behalf of The American Association for Thoracic Surgery
https://doi.org/10.1016/j.jtcvs. 2019.10 .014

Ann Arbor, Mich.
Disclosures: Author has nothing to disclose with regard to commercial support.
Received for publication Oct 8, 2019; revisions received Oct 8, 2019; accepted for publication Oct 8, 2019
available ahead of print Nov 11, 2019.
Address for reprints: Ming-Sing Si, MD, 11-735 C.S. Mott Children's Hospital SPC 4204, 1540 E Hospital D
Ann Arbor, MI 48109-4204 (E-mail: mingsing@ umich.edu).
J Thorac Cardiovasc Surg 2020;159:1984-5
0022-5223/\$36.00
Copyright @ 2019 Published by Elsevier Inc. on behalf of The American Association for Thoracic Surgery
https://doi.org/10.1016/j.jtcvs.2019.10.014

Ann Arbor, Mich.
Disclosures: Author has nothing to disclose with regard to commercial support.
Received for publication Oct 8,$2019 ;$ revisions received Oct 8, 2019; accepted for publication Oct 8, 2019;
available ahead of print Nov 11, 2019.
Address for reprints: Ming-Sing Si, MD, 11-735 C.S. Mott Children's Hospital SPC 4204, 1540 E Hospital Dr,
Ann Arbor, MI 48109-4204 (E-mail: mingsing@umich.edu).
J Thorac Cardiovasc Surg 2020;159:1984-5
0022-5223/\$36.00
Copyright $\subset 2019$ Published by Elsevier Inc. on behalf of The American Association for Thoracic Surgery
https://doi.org/10.1016/j.jtcvs. 2019.10 .014

Ann Arbor, Mich.
Disclosures: Author has nothing to disclose with regard to commercial support.
Received for publication Oct 8, 2019; revisions received Oct 8, 2019; accepted for publication Oct 8, 2019
available ahead of print Nov 11, 2019.
Address for reprints: Ming-Sing Si, MD, 11-735 C.S. Mott Children's Hospital SPC 4204, 1540 E Hospital D
Ann Arbor, MI 48109-4204 (E-mail: mingsing@ umich.edu).
J Thorac Cardiovasc Surg 2020;159:1984-5
0022-5223/\$36.00
Copyright @ 2019 Published by Elsevier Inc. on behalf of The American Association for Thoracic Surgery
https://doi.org/10.1016/j.jtcvs.2019.10.014

Ann Arbor, Mich.
Disclosures: Author has nothing to disclose with regard to commercial support.
Received for publication Oct 8, 2019; revisions received Oct 8, 2019; accepted for publication Oct 8, 2019
available ahead of print Nov 11, 2019.
Address for reprints: Ming-Sing Si, MD, 11-735 C.S. Mott Children's Hospital SPC 4204, 1540 E Hospital D
Ann Arbor, MI 48109-4204 (E-mail: mingsing@ umich.edu).
J Thorac Cardiovasc Surg 2020;159:1984-5
0022-5223/\$36.00
Copyright @ 2019 Published by Elsevier Inc. on behalf of The American Association for Thoracic Surgery
https://doi.org/10.1016/j.jtcvs.2019.10.014

Ann Arbor, Mich.
Disclosures: Author has nothing to disclose with regard to commercial support.
Received for publication Oct 8, 2019; revisions received Oct 8, 2019; accepted for publication Oct 8, 2019
available ahead of print Nov 11, 2019.
Address for reprints: Ming-Sing Si, MD, 11-735 C.S. Mott Children's Hospital SPC 4204, 1540 E Hospital D
Ann Arbor, MI 48109-4204 (E-mail: mingsing@ umich.edu).
J Thorac Cardiovasc Surg 2020;159:1984-5
0022-5223/\$36.00
Copyright @ 2019 Published by Elsevier Inc. on behalf of The American Association for Thoracic Surgery
https://doi.org/10.1016/j.jtcvs.2019.10.014

Ann Arbor, Mich.
Disclosures: Author has nothing to disclose with regard to commercial support.
Received for publication Oct 8, 2019; revisions received Oct 8, 2019; accepted for publication Oct 8, 2019
available ahead of print Nov 11, 2019.
Address for reprints: Ming-Sing Si, MD, 11-735 C.S. Mott Children's Hospital SPC 4204, 1540 E Hospital D
Ann Arbor, MI 48109-4204 (E-mail: mingsing@ umich.edu).
J Thorac Cardiovasc Surg 2020;159:1984-5
0022-5223/\$36.00
Copyright @ 2019 Published by Elsevier Inc. on behalf of The American Association for Thoracic Surgery
https://doi.org/10.1016/j.jtcvs.2019.10.014

Ann Arbor, Mich.
Disclosures: Author has nothing to disclose with regard to commercial support.
Received for publication Oct 8, 2019; revisions received Oct 8, 2019; accepted for publication Oct 8, 2019
available ahead of print Nov 11, 2019.
Address for reprints: Ming-Sing Si, MD, 11-735 C.S. Mott Children's Hospital SPC 4204, 1540 E Hospital D
Ann Arbor, MI 48109-4204 (E-mail: mingsing@ umich.edu).
J Thorac Cardiovasc Surg 2020;159:1984-5
0022-5223/\$36.00
Copyright @ 2019 Published by Elsevier Inc. on behalf of The American Association for Thoracic Surgery
https://doi.org/10.1016/j.jtcvs.2019.10.014 term studies from this group will need to demonstrate that the tissue-engineered vascular graft possesses appropriate growth potential. The investigators also did not provide right ventricle pressure measurement, and therefore we do not know whether the narrowing in the proximal main pulmonary artery/anastomosis in Figure 3 of their paper was significant. Despite these potential shortcomings of their tissue-engineered vascular graft in this small pilot study, these results represent a substantial and pivotal milestone, as their innovative strategy combines various techniques to create a personalized, tissue-engineered vascular graft that is complex in shape. Furthermore, the tissueengineered vascular graft demonstrates promising evidence of in vivo cellularization, remodeling, and maturation.

Most vascular patches and grafts are implanted in cardiovascular structures with high-pressure conditions, and further evolution of the technique of Yeing and colleagues to create, for example, personalized arch patches, intracardiac baffles, and grafts for major aortopulmonary collateral arteries, would have significant potential to improve shortand longer-term outcomes of many congenital heart surgical procedures. Determining the optimal material or material blend that would render more robust biomechanical characteristics while promoting the appropriate in vivo cellularization is likely the rate-limiting step in achieving these game-changing, personalized implants. Nevertheless, these authors should be congratulated for accomplishing this important study. 


\section{References}

1. Emmert MY, Fioretta ES, Hoerstrup SP. Translational challenges in cardiovascular tissue engineering. J Cardiovasc Transl Res. 2017;10:139-49.

2. Olds A, Nakamura Y, Levasseur S, Shah A, Freud L, Chelliah A, et al. Outcomes of surgical repair of complex D-transposition of the great arteries. World J Pediatr Congenit Heart Surg. 2018;9:605-12.

3. Cleveland DC, Kirklin JK, Pavnica JW, Tresler MA, Kukreja M, Dabal RJ, et al. Late left ventricular outflow tract obstruction following the Rastelli operation: expectations out to 20 years. World J Pediatr Congenit Heart Surg. 2016;7:605-10.

4. Yeing E, Inoue T, Matsushita H, Opfermann J, Mass P, Aslan S, et al. In vivo implantation of 3D printed customized branched tissue engineered vascular graft in porcine model. J Thorac Cardiovasc Surg. 2020;159:1971-81.e1. 